\title{
Afonso Celso Junior: um jovem republicano conservador
}

\author{
Afonso Celso Junior: A young conservative republican
}

\author{
Alexandra do Nascimento Aguiar \\ Doutora em História \\ Professora da Secretaria Estadual de Educação \\ alexaaguiar13@gmail.com
}

Resumo: Afonso Celso de Assis Figueiredo Junior foi um político em ascensão no final do Segundo Reinado e reconhecido como intelectual na Primeira República. Foi militante no movimento republicano e, mesmo eleito deputado pelo Partido Liberal, permaneceu apologista da República durante a Monarquia. Através de sua trajetória de militante republicano eleito para deputado imperial, o presente artigo tem como proposta analisar a concepção de República defendida pelo jovem Afonso Celso Junior em seu discurso de estreia como parlamentar. Este ocorreu na primeira Câmara dos Deputados eleita por voto direto no Brasil, resultado da Lei Saraiva (1881), cenário de expectativas de renovação política e que não se concretizaram.

Palavras-chave: Afonso Celso Junior, República, Lei Saraiva.

\begin{abstract}
Afonso Celso de Assis Figueiredo Junior was a rising politician at the end of the Second Reign and recognized as an intellectual in the First Republic. He was a militant in the republican movement and, even elected deputy for the Liberal Party, remained apologist of the Republic during the Monarchy. Through his trajectory of Republican militant to the imperial deputy, the present article has like proposal to analyze the conception of Republic defended by the young Afonso Celso Junior in his speech of debut like parliamentarian. This occurred in the first Chamber of Deputies elected by direct vote in Brazil, a result of the Saraiva Law (1881), a scenario of expectations of political renewal that did not materialize.
\end{abstract}

Key-word: Afonso Celso Junior, Republic, Saraiva Law. 


\section{Apresentação}

O conto Teoria do Medalhão $o^{1}$, de Machado de Assis, narra o diálogo entre pai e filho na noite em que o último alcança a maioridade. O pai oferece ensinamentos sobre a vida ao filho para que este se torne alguém proeminente, um medalhão. Ele o orienta a se conduzir de acordo com a boa sociedade ${ }^{2}$ (MATTOS, 1986: 117), não se descuidar das aparências e nunca levantar questões incômodas nas rodas sociais. Na narrativa, o velho ensina ao novo a ser velho, sua vivência é transmitida ao jovem através das experiências, recurso literário que remete ao Príncipe, de Maquiavel, segundo a análise de Bosi sobre o mesmo conto (BOSI, 2007: 75-125). Entre os conselhos paternos do personagem, inclui-se a política, não associar ideologia à identidade partidária, "pode-se pertencer a qualquer partido, liberal ou conservador, republicano ou ultramontano, com a cláusula única de não ligar nenhuma ideia especial a esses vocábulos”, pois os partidos apenas funcionariam como senhas para o ingresso na carreira política.

Como toda a obra machadiana permite olhares diversos sobre a sociedade oitocentista, no presente artigo, o conto nos serve de reflexão sobre a iniciação na política pelo intelectual Afonso Celso de Assis Figueiredo Junior ou Conde de Afonso Celso (1860-1938). Apenas coincidência ou não, Teoria do Medalhão foi publicado no período de término da apuração das eleições de 1881, fruto da Lei Saraiva que introduziu a eleição direta no Brasil. A reforma, que se propôs inovadora, elegeu os nomes experientes no jogo político, os "medalhões" que daria a cor conservadora à primeira Câmara eleita por voto direto, e cenário do deputado estreante Afonso Celso Junior, republicano eleito pelo Partido Liberal.

A biografia de Afonso Celso de Assis Figueiredo Jr. já é bastante conhecida, cabem apenas algumas linhas que acentuam sua trajetória como herdeiro político do pai Afonso Celso de Assis Figueiredo (Visconde de Ouro Preto), condição para sua eleição e que o próprio ressaltou em suas memórias:

Assacam-me assiduamente a pecha de ter sido eleito sem elementos próprios, graças apenas ao prestígio de meu pai. [...] O único protetor e chefe que tive na carreira política e quem me abriu portas dessa carreira foi o visconde de

\footnotetext{
${ }^{1} \mathrm{O}$ conto foi publicado no jornal Gazeta de Notícias, 18 de dezembro de 1881, p. 1.

2 Adoto como definição para a boa sociedade o grupo social constituído por brancos, livres e proprietários identificados à aristocracia e ao "mundo do governo".
} 
Ouro Preto. As recomendações de que proveio o meu ingresso no parlamento devo-as a ele exclusivamente (AFONSO CELSO, 1998: 19).

O Visconde de Ouro Preto foi político relevante no Império, ocupou os cargos de deputado, senador, ministro e, por fim, foi presidente do Conselho no último Gabinete da monarquia (Jul.-Nov./1889), com o golpe militar que implantou a República, foi preso e seguiu para o exílio.

Afonso Celso Jr. também contava, ao seu lado, com o tio Carlos Afonso de Assis Figueiredo, também eleito deputado em 1881, e reeleito outras vezes e depois ministro, a exemplo do irmão mais velho.

Afonso Celso Jr. começou se destacar como promessa intelectual ainda estudante na Faculdade de Direito em São Paulo, onde também integrou o movimento republicano. Suas primeiras produções datam de 1876, os livros de poesias Devaneios e Prelúdios, além de breve incursão pelo teatro ${ }^{3}$ (1879) e a publicação de um tributo ao tricentenário da morte de Luís de Camões, em 1880. Esta última recebeu maior atenção na imprensa paulistana, em parte pela notoriedade do jovem estudante, poeta e militante republicano, e também pela acusação de plágio contra ele. A primeira carta a expor a dúvida sobre a integralidade da autoria do livro Camões por Afonso Celso sugere que a denúncia partiu de um colega da faculdade, sob o pseudônimo de Reis - o traidor, e oferece também uma visão sobre a ambiência intelectual compartilhada por Afonso Celso Jr.:

Eu sou daqueles, amigo, que, desde que nos matriculamos em 76, tem levado a vida bem longe dos burburinhos acadêmicos.

Vejo, do meu retiro, deslizarem os filósofos, os jurisconsultos, os jornalistas e até os poetas, e os olho com um sorriso de desdém e compaixão. [...]

Foi nessa paz beatifica de uma descrença spleenetica, que me introduziram nas mãos um "livrinhozinho", dizendo ser teu.

Uns colegas convidaram-me para tomar chá. Oh! Um chá filado em uma república val'um poema! E a boa prosa! E tudo!

Mas que engano! Apenas sento-me à mesa, surge um dos republicanos com quatro livros.

Que horror! Ia ser caceteado, mas... esperei.

3 “?” - Um ponto de interrogação, peça em cartaz no Teatro S. José. 
Eis senão quando dão-me o teu livreco "Camões"... (JORNAL DA TARDE, $21 / 06 / 1880)$.

A partir desse trecho, o autor da carta cita as páginas em que estariam as supostas cópias e prossegue, em tom irônico, indicando que este não era um caso isolado, pois as conferências de Afonso Celso Jr. e de seus amigos republicanos também não seriam autênticas. Seguiram-se outras cartas com o mesmo teor, e uma em defesa, cujo autor se identificou como Ignácio, criado de Afonso Celso, o que levou à especulação se o próprio não havia inventado esse personagem. Afonso Celso preferiu não responder às denúncias, explicando-se no mesmo jornal que não discutiria com "anônimos"4.

O episódio não comprometeria sua atuação como intelectual, cuja produção seria expressiva na República ${ }^{5}$, e foi plenamente analisada por Guimarães (GUIMARÃES, 2003) ao trazer o caráter ultramontano das obras de Afonso Celso e as metamorfoses do político e intelectual. Desde que foi deputado republicano no Partido Liberal, passando à marginalidade política na República, e reaproximação com os monarquistas e, por fim, sua renúncia à política, dedicando-se à vida acadêmica e devotando-se ao catolicismo, através de doações financeiras e articulações para a construção de igrejas na cidade de Petrópolis ${ }^{6}$, motivo pelo qual receberia o título de Conde de Afonso Celso, em 1905, concedido pelo Papa Pio X. Afonso Celso ingressou no Instituto Histórico e Geográfico Brasileiro em 1892, na qual foi presidente perpétuo entre 1912 e 1938, ano em que faleceu. Também foi um dos membros fundadores da Academia Brasileira de Letras, além de professor na Faculdade de Ciências Jurídicas e Sociais do Rio de Janeiro, depois reitor da Universidade. Escreveu artigos para diversos periódicos, como o Jornal do Brasil, a Gazeta da Tarde, a Gazeta de Petrópolis, entre outros (FRÓES, 1960: 269-281).

Através do discurso de Afonso Celso Jr. em sua primeira apresentação pública no plenário, pretendo analisar o modelo de República almejado pelo jovem deputado, pois, como foi lembrado por Guimarães, sobre ele era dito "republicano no Império, monarquista na República”. O Afonso Celso Jr. que ingressou como deputado no Parlamento, em 1881, defendia uma República que privilegiaria as camadas médias e

\footnotetext{
${ }^{4}$ As cartas foram publicadas no Jornal da Tarde, 21, 22 e 23 de junho de 1880.

${ }^{5}$ Vultos e fatos (1892); O Imperador no exílio (1893); Lupe (1894); Guerrilhas (1895); Um invejado (1895); Giovannina (1896); Contraditas monárquicas (1896); O Assassinato do Coronel Gentil José de Castro: (subsídios para a história do regimento republicano no Brasil) (1897); Porque me ufano do meu país (1901), Oito anos de parlamento (1901).

${ }^{6}$ Cidade do estado do Rio de Janeiro, onde Afonso Celso residiu e foi figura eminente na sociedade petropolitana.
} 
estava acima das questões sociais, e ainda não poderia ser classificado como abolicionista, o que só aconteceria a partir de 1884 .

A militância de Afonso Celso Jr. no movimento republicano se mostrou veemente como estudante de Direito na capital paulista, tornou-se membro do Clube Republicano Acadêmico, "redator em chefe" do jornal acadêmico A República, e foi eleito presidente da agremiação em 18807. Em um protesto de estudantes na Faculdade de Direito, em abril de 1879, a fala desafiadora de Afonso Celso Jr. contra uma autoridade do governo Liberal foi exaltada por outro deputado do Partido Conservador, "devo lembrar o dito de um distinto moço, que constitui uma das glórias da atual geração acadêmica, o Sr. Afonso Celso Junior que, interpelando energicamente o trêmulo presidente, disse-lhe: 'a polícia de V. Excia acreditava que a academia de S. Paulo era uma matriz em dia de eleições!’” (CORREIO PAULISTANO, 20/04/1879). Possivelmente por esse episódio, em novembro do mesmo ano, o Partido Liberal, sob a influência do visconde de Ouro Preto, incluiu Afonso como candidato a deputado provincial por Minas Gerais. Candidatura que ele recusou, alegando não ter idade suficiente para concorrer e, principalmente, por sua fidelidade ao Partido Republicano (GAZETA DE NOTÍCIAS, 05/11/1879) ${ }^{8}$.

O engajamento de Afonso Celso Jr. no movimento republicano o levou a apresentar a primeira conferência no Clube Republicano Acadêmico, em que discorreu sobre "Comunismo, socialismo e niilismo na Europa". Segundo nota na imprensa, "a concorrência foi numerosa e o inteligente preletor houve-se na altura de suas forças intelectuais" (JORNAL DA TARDE, 30/05/1880).

Em 1880, uma mensagem do Clube Republicano Acadêmico em apoio à “posição enérgica" de José do Patrocínio na imprensa da Corte marcou o início da divergência entre Afonso Celso Jr. e a agremiação. Dois dias depois, o Jornal da Tarde publicaria uma nota esclarecendo que Afonso Celso foi contrário ao clube enaltecer Patrocínio, e que apenas permitiu que a votação sobre esse tema transcorresse porque ele, como presidente da agremiação, não pôde interferir. Como a aprovação sobre a menção à

\footnotetext{
${ }^{7}$ O crescimento de Afonso Celso Jr. no Club Republicano Acadêmico em notas nos periódicos Correio Paulistano, 21 de março de 1879 e Jornal da tarde, 04 de julho de 1880.

${ }^{8}$ O Partido Republicano surgiu como dissidência radical do Partido Liberal de 1869. Desde o Manifesto Republicano de 1870 até a primeira metade dos anos 1880, a candidatura de republicanos pelos partidos imperiais, em especial pelo Partido Liberal, era estratégia conhecida e frequente para conseguirem ingressar na Assembleia Geral.
} 
Patrocínio foi unânime, Afonso Celso Jr. renunciou ao cargo, justificando sua atitude por motivos "particulares".

Os motivos pessoais estavam ligados ao seu pai, Visconde de Ouro Preto, que havia sido ministro da fazenda no Gabinete de Sinimbu e autor do imposto sobre a tarifa dos bondes que motivou a Revolta do Vintém, e por isso se tornou alvo de críticas da Gazeta da Tarde ${ }^{10}$, comprado por Patrocínio. Jornal que se tornou um dos principais veículos de propaganda abolicionista, contava com redatores republicanos, como o próprio Patrocínio, e que publicavam constantes censuras ao governo (ALONSO, 2013: 118-119). Pairava ainda sobre o governo Liberal, chefiado por Saraiva naquele momento, certa resistência devido à recusa em debater sobre a reforma do trabalho escravo. E contra o senador Afonso Celso, além do tributo do vintém já revogado, pesava sua posição refratária ao abolicionismo. Sob o título de "Máximas escravocratas", a Gazeta da Tarde divulgou os nomes e as respectivas falas dos políticos do Partido Liberal e do Partido Conservador contrárias ao fim imediato da escravidão, e entre elas estava a do senador Afonso Celso, cuja opinião era de que "os loucos que falam em abolição querem desacreditar o Partido Liberal" (GAZETA DA TARDE, 25/09/1880). A partir desse quadro a relação entre Afonso Celso Jr. e Patrocínio foi inamistosa, chegando à luta corporal de fato $^{11}$.

O ano 1880 também seria o último de Afonso Celso Jr. como estudante, com a defesa da tese "Direito da Revolução" ele se bacharelou como advogado e, finalmente, cedeu ao ingresso na política via Partido Liberal. Acompanhado de um amigo da família e sob o prestígio do pai, Afonso Celso visitou distritos em Minas Gerais e outras províncias, até que se viu deputado geral: "Que intensa emoção - misto de contentamento, receio, ambição de glória, desejo de trabalhar, esperança, desencanto na hora em que me vi proclamado um dos legisladores do meu país!" (AFONSO CELSO, 1998: 22).

\footnotetext{
${ }^{9}$ A nota sobre o apoio do Club Republicano Acadêmico à Patrocínio e a reação de Afonso Celso Jr. à publicação aparecem no Jornal da Tarde, 25 de julho e 27 de julho de 1880.

${ }^{10}$ Gazeta da Tarde, 23 de julho de 1880 e 09 de setembro de 1880.

${ }^{11}$ Em junho de 1883, José do Patrocínio denunciou em seu jornal a agressão de Afonso Celso Jr. contra ele, ocorrida no Teatro Pedro II. Segundo Patrocínio, Afonso Celso Jr. o teria atingido com uma bengala com o objetivo de derrubá-lo da escada. Os dois iniciaram uma luta corporal, impedida por amigos do abolicionista e por policiais que contiveram o deputado. $\mathrm{O}$ episódio foi comentado e criticado em vários jornais da época: Gazeta da Tarde, 04 de junho de 1883.
} 


\section{O jovem deputado Afonso Celso Junior}

Quando iniciou na deputação em 1882, o panorama político ainda era de euforia com os resultados da eleição direta. O Partido Liberal fora vitorioso na realização da reforma eleitoral e nas urnas, compunha a maioria da representação na Câmara dos Deputados e dividia o plenário com o Partido Conservador em número expressivo. Criar espaço para a oposição no Parlamento era um dos objetivos da reforma, que elegeu 75 liberais contra 47 conservadores. Para a presidência do Conselho fora convidado Martinho Álvares da Silva Campos, "escravocrata da gema" manifesto ${ }^{12}$, e de quem Afonso Celso Jr. guardou as primeiras impressões e teria as primeiras lições no Parlamento.

Martinho Campos, eleito deputado também pela província mineira, era personalidade controversa no Partido Liberal, sendo visto como conservador dentro de seu próprio partido, pois suas ideias encontravam apoio no Partido Conservador, entre elas a resistência em avançar com a emancipação. Pedro II convidou Martinho Campos para a Presidência do Conselho no momento em que a escravidão voltava ao debate, para tranquilizar os ânimos dos dois lados, pois Campos era "aceitável para muitos liberais, por ser um deles, mas inimigo de qualquer alteração no estatuto do trabalhador escravo" (HOLANDA, 2008: 125-126). Ao assumir a presidência do Conselho, ele se referiu àquele cenário político de harmonia partidária, pelo menos aparente, criado pela Lei Saraiva, como "[...] são duas coisas muito parecidas - um liberal e um conservador - e podia mesmo acrescentar um republicano [...]. Vivemos às mil maravilhas, na mesma canoa e não temos dificuldades quanto às opiniões" (Anais da Câmara dos Deputados, 24 de janeiro de 1882).

Em suas memórias políticas, registradas em Oito anos no parlamento, Afonso Celso Jr. destaca os conselhos que recebeu de Martinho Campos para que ele fosse bem sucedido na vida parlamentar. Palavras de um político sexagenário ao jovem deputado iniciante de 21 anos: necessário não se desentender com o presidente da Câmara, "pode ataca-lo, mas com jeito"; não agredir o adversário de forma inconciliável, pois "o mundo e a política dão imensas voltas"; não se ausentar por muito tempo do plenário nem conversar demais pelos corredores, "evitam-se intrigas"; atentar ao que você disser em

\footnotetext{
12 A declaração de Martinho Campos encontra-se nos Anais da Câmara dos Deputados, sessão de 28 de fevereiro de 1882 e também foi citada por Afonso Celso Jr. em Oito anos no Parlamento.
} 
público porque "tudo quanto se fala repercute", e marcar presença em suas falas mostrando que "não engole desaforos" (AFONSO CELSO, 1998: 34).

Em sua primeira apresentação pública como parlamentar, o jovem demonstrou independência em relação à orientação política de seu pai, assumiu-se republicano. Assinando na fileira de oposição ao programa de governo do seu próprio partido, o deputado marcava posição como representante da nova geração de políticos que não se reconhecia nos partidos imperiais. A situação não era inusitada, pois republicanos confessos ingressavam nos partidos imperiais como estratégia, candidatando-se de acordo com a filiação partidária da família ou dos padrinhos políticos.

Inicialmente, o republicanismo atraiu estudantes sem expectativa de inserção no Estado, jovens herdeiros que associavam o regime ao progresso e profissionais liberais sem perspectivas na monarquia. Posteriormente, os fazendeiros se aproximaram das ideias republicanas, especialmente pela defesa do federalismo, alcançando adesão significativa em São Paulo, onde foi fundado o primeiro Partido Republicano (Convenção de Itu de 1873). O republicanismo conquistou espaço nas províncias de predomínio do Partido Liberal ou naquelas que haviam se inclinado ao republicanismo dos liberais exaltados no passado (LEMOS, 2009: 414). Ao longo dos anos 1880, o Partido Republicano foi organizado em outras províncias, porém sem representação política significativa no Parlamento.

Sem poder contar com um partido consolidado em todas as províncias, os republicanos atuavam nos clubes e jornais, divulgando as ideias contidas no Manifesto Republicano de 1870, dividindo-se entre a "revolução" de Silva Jardim e a "evolução" de Quintino Bocaiuva, dois expoentes do movimento. A corrente revolucionária de Silva Jardim seguia o republicanismo francês e abarcava a participação popular, não descartando derrubar a monarquia com armas. Enquanto a evolucionista, por Quintino Bocaiuva, doutrinava sobre a república como modelo ideal de governo. Por esta corrente, a república substituiria a monarquia sem insurreições e o país seria reorganizado de acordo com o republicanismo norte-americano, visando prioritariamente atender as questões de Estado (LEMOS, 2009: 417-418). O republicanismo evolucionista foi a via escolhida por Afonso Celso Jr.

As propostas no Manifesto Republicano de 1870 mostravam-se mais contidas do que aquelas do Partido Liberal de 1869. As principais ideias do Manifesto Republicano eram a descentralização político-administrativa e a crítica ao regime monárquico hereditário como não democrático. No entanto, para os republicanos, a reforma se 
limitava à reorganização política e não mencionava aspectos sociais, entre os quais a abolição do trabalho escravo (CARVALHO, 2007).

O discurso de Afonso Celso Jr., analisado neste artigo, ocorreu em 28 de fevereiro de 1882, como resposta à Fala do Trono ${ }^{13}$, na abertura das atividades na Assembleia Geral. Ele começou por distinguir os dois partidos, o Conservador, "da fidelidade rigorosa à Constituição, da resistência às inovações...”, em contraste ao Liberal, mencionando a história do partido e suas bandeiras nos anos de 1831, 1862, 1867, 1868 e 1869, quando se posicionou "reforma e revolução". Definindo-se na política partidária, Afonso Celso Jr. provocou os parlamentares que o ouviam: "De que lado assentarei a minha tenda de campanha? Quais as cores que figuram na flamula das minhas opiniões?... (Pausa.) [...] Eu sou, tenho sido sempre e me preso de ser republicano". Sua orientação seria o Manifesto de 1870, cuja pauta era reformar sem "convulsionar a sociedade", promovendo debates doutrinários e sem estimular discórdias, "porém simplesmente a reconstrução moral". A República e o federalismo seriam instaurados através de uma constituinte, que adequaria a sociedade ao governo republicano (ANAIS DA CÂMARA DOS DEPUTADOS, 28/02/1882).

A República idealizada até a primeira metade do século XIX guardava as imagens das revoluções do último quartel do século XVIII, a Independência das Treze Colônias inglesas na América e a Revolução Francesa, porém em especial a última, pois remetia à radicalização e à ruptura política com convulsão social pelo protagonismo do povo. $\mathrm{Na}$ segunda metade, a República seria reapresentada a partir da experiência pós Independência das Treze Colônias, o modelo republicano inspirado pelos Estados Unidos da América era de estabilidade e participação política moderada. Os signatários do Manifesto de 1870 acreditavam em interiorizar o novo regime penetrando nas estruturas políticas e sociais, em oposição aos primeiros militantes radicais ou românticos que visavam impor os ideais republicanos pela derrubada de governos e mobilização popular, segundo sua opinião:

[...] outros quiseram daí explorar as paixões da turba, tornando-se seus cortesãos, esquecidos de que esse mister é mais triste do que o dos aduladores dos reis (apoiados gerais); porque estes já quase nada podem dar, ao passo que aquela concede as vanglórias do amor próprio e as satisfações da vaidade, não compreendendo que querem tirar a soberania absoluta dos monarcas para a

\footnotetext{
${ }^{13}$ Anais da Câmara dos Deputados, Fala do Trono, 17 de janeiro de 1882.
} 
darem ao poviléu; outros, finalmente, imbuídos da leitura das velhas revoluções, entusiastas românticos, inofensivos e bons, transportam para o terreno público os tipos dos romances, e, vendo por toda a parte tiranos e guilhotinas, verdadeiros histéricos políticos, superficiais e gritadores, só pretendem destruir, sem cuidar da reedificação (ANAIS DA CÂMARA DOS DEPUTADOS, 28/02/1882).

A proposta era doutrinar a partir das camadas médias para evitar a radicalização, uma das razões pela qual Afonso Celso Jr. rejeitava os clubes republicanos, igualmente criticados por Quintino Bocaiuva, que se assemelhavam às "assembleias tumultuárias, sem individualização, nem responsabilidade; e aspirando a reformas radicais" (Anais da Câmara dos Deputados, 28 de fevereiro de 1882). A opinião do deputado sobre como as transformações deveriam operar na sociedade demonstra uma visão conservadora, segundo ele, a "república é a mais elevada expressão do progresso na direção dos povos, mas que esse progresso só se realiza gradativamente, pois a ordem natural é caminhar e não saltar". A República no Brasil seria realizada dentro da legalidade:

Na América, as repúblicas espanholas que substituíram, de repente, a forma colonial pelo regime republicano, à exceção do Chile que passa pela última prova e da República Argentina que ultimamente tem gozado de alguns anos de paz, vemo-las todas a se estorcerem na anarquia, pervertendo os costumes políticos, imolando as piras das discórdias a liberdade de que se dizem filhas (Apoiados gerais). Na Europa, a França, onde ao poder absoluto sucedeu inopinadamente a República [...]. Ainda lá, ao simulacro do governo constitucional de Luiz Felipe seguiu-se a república de 1848, que logo desapareceu ante um despotismo pior do que o do $1^{\circ}$ imperador [...] (ANAIS DA CÂMARA DOS DEPUTADOS, 28/02/1882).

Afonso Celso incluiu a República francesa entre os modelos negativos do regime porque proveniente de uma revolução se tornaria um governo instável e terreno fértil para golpes e autoritarismos. Governos arbitrários exemplificados através de Bonaparte e de Luís Felipe, a queda deste último levaria à Segunda República e a ascensão de Luís Bonaparte através das urnas. A censura de Afonso Celso era dirigida contra os governos estabelecidos sobre a manipulação das massas e originários das multidões. 
A figura de Luís Bonaparte estava associada ao sufrágio universal na França no contexto das revoluções de 1848, protagonizadas por socialistas, republicanos e pelos trabalhadores em reação ao recrudescimento da crise econômica e da miséria. A série de levantes violentos nas ruas de Paris intimidou a burguesia e provocou a renúncia do rei Luís Filipe, encerrando a Monarquia de Julho e iniciando a Segunda República e a conquista do voto universal masculino.

Nesse cenário Luís Bonaparte emergiu sobre a memória do "suposto" tio, Napoleão Bonaparte, e conseguiu apoio popular se apropriando do discurso dos movimentos revolucionários e de trabalhadores. Recebeu atenção dos operários e dos camponeses com o panfleto A Extinção do Pauperismo (1844), através do qual pregava a defesa dos mais pobres contra a exploração. Após uma temporada de autoexílio na Inglaterra, Bonaparte retornou à França, em 1848, e, aproveitando-se do quadro político, concorreu à presidência da República pelo Partido da Ordem. Sua vitória foi impulsionada pelo receio dos camponeses, dos monarquistas, da burguesia e dos católicos às ideias socialistas disseminadas entre os trabalhadores urbanos. Eleito com $70 \%$ dos votos, predominantemente pelo campesinato, e com a popularidade em alta, Luís Bonaparte não aceitou deixar o poder no fim do mandato. Como a Constituição não permitia reeleição, ele estendeu sua permanência na presidência através de um golpe e pôs fim ao governo republicano, através de plebiscito instituiu o Segundo Império e coroou-se Imperador Napoleão III (DEBON, 2015: 332-355).

Afonso Celso Jr. considerava o sufrágio universal e a eleição de Luís Bonaparte como desventura política que reafirmava seus temores sobre a demagogia e sobre a democracia. Os homens comuns votavam orientados pelas emoções e eram manipulados pelos demagogos que se promoviam nos períodos de instabilidade generalizada, em especial nas crises econômicas que atingiam de forma mais intensa as camadas mais pobres. Tal percepção sobre o despreparo da população para a participação política é evidente quando ele distingue entre os comportamentos da "massa" e da minoria instruída sobre o republicanismo. Os primeiros, frequentadores de clubes, não compreendiam o impacto de uma revolução sobre o destino do país. Os segundos almejavam convencer através da propaganda, pela conscientização sobre o novo regime:

Meu partido ainda não se acha, infelizmente, organizado, qual o exige o manifesto de 1870, pois só um ou outro correligionário convencido patrocina com coragem e talento a causa comum, enquanto a massa, a generalidade dos 
que dizem-se republicanos hostiliza-a e pensa poder edificar sobre as ruinas dos homens e das coisas, quando só do país podem vir os materiais, e estes não se encontram onde há apenas destroços - sem bússola, sem rumo certo, enoveladas nas mil dobras de uma anarquia fatal (ANAIS DA CÂMARA DOS DEPUTADOS, 28/02/1882).

Ele acreditava que o Partido Republicano se fortaleceria no Brasil como transformação "evolucionista" dentro da monarquia e não como ruptura, "o Partido Republicano não será um membro dissidente da família brasileira”. A República aconteceria "como fiel expressão da vontade nacional sem as oscilações das surpresas ou os funestos arrastamentos das paixões" (ANAIS DA CÂMARA DOS DEPUTADOS, 28/02/ 1882).

O deputado Francisco Inácio Carvalho de Rezende, do Partido Conservador de Minas Gerais, provocou o jovem lhe perguntando se havia informado aos eleitores durante a campanha sobre suas ideias republicanas, considerando que o distrito por onde se elegeu era Liberal. Afonso Celso Jr. justificou sua adesão ao Partido Liberal devido ao Partido Republicano ainda não estar organizado em sua província, e por ver os liberais como "aliados naturais" pela semelhança nos propósitos reformistas. Porém, seus argumentos se mostravam contraditórios sobre a associação dos republicanos aos partidos imperiais:

A qual deles poderei auxiliar? Ao conservador, como alguns dos meus correligionários de S. Paulo? Nunca, porque seria concorrer para o triunfo da ideia diametralmente oposta a minhas crenças, e, se isto não é trai-las, é, pelo menos, demorar a sua vitória. Seria uma aliança hibrida só própria para gerar monstruosidades, pois o que é senão uma monstruosidade na ordem moral um republicano escravista? [...] (ANAIS DA CÂMARA DOS DEPUTADOS, 28/02/1882).

Durante a década em que o Partido Liberal esteve afastado dos governos (18681878), os republicanos mantiveram relação, qualificada por Holanda, de "promiscuidade" com os liberais, unindo-se a eles apenas por interesses eleitorais. A partir de 1878, quando os liberais voltaram a governar e muitos republicanos se elegeram com eles, destacadamente os paulistas passaram a se expor como republicanos e a apoiar o Partido Conservador (HOLANDA, 2008: 308). Essa inclinação dos republicanos de São Paulo 
ao Partido Conservador foi observada por Afonso Celso Jr., que admitiu ele mesmo ter afinidade com os conservadores, "confesso que apesar de republicano tenho tendências conservadoras em algumas ideias, mas não me ligo ao Partido Conservador. [...] Sou republicano conservador, é verdade; estabelecida a república hei de seguir Gambetta e não Luiza Michel [Louise Michel]" (ANAIS DA CÂMARA DOS DEPUTADOS, 28/02/1882).

Ele se referia à III República implantada na França e que teve Leon Gambetta como um dos expoentes do governo que derrubou o Segundo Império de Napoleão III e, posteriormente, como defensor de uma vertente republicana conservadora e progressista moderada. Esta era conservadora porque visava a "manutenção da estabilidade e da integridade do tecido social e para eliminar a solução violenta dos conflitos". Compreendia reformas progressistas moderadas, respeitando o tempo necessário para seus resultados e não através de revolução. A República almejada por Gambetta era mesocrática, apoiava-se nas classes médias rurais e urbanas, rejeitava o socialismo e era anticlerical, sustentava a separação entre Igreja e Estado e a necessidade da educação laica como instrumento contra as "superstições" e para fortalecer a pátria. Louise Michel emergiria no mesmo contexto, porém em posição oposta, como uma das lideranças na Comuna de Paris, (março-maio/1871), movimento que abarcou socialistas, anarquistas, republicanos e antigos jacobinos, e cujo estopim foi a paz assinada pelo governo de Thiers, e que derrubou o Segundo Império. A insurreição trazia reivindicações econômicas e sociais, por educação laica e gratuita, por igualdade para as mulheres e por direitos para a classe trabalhadora. O movimento foi esmagado pelo Estado através de fuzilamentos, prisões e exílios, reforçando a "imagem da Terceira República como 'República da ordem'”, (ALCAÑIZ, 2005).

A opção de Afonso Celso Jr. era pela República em que a organização do Estado se sobrepunha às questões sociais, estas tratadas pelo alto e sem o protagonismo das ruas. Deputados do Partido Conservador ironizaram sua declaração sobre seu republicanismo conservador, relembrando a comparação feita pelo presidente do Conselho, Martinho Campos, sobre seu governo como uma canoa que comportava diversidades partidárias ${ }^{14}$ :

O Sr. Lacerda Werneck: - não entre na canoa. (hilaridade)

\footnotetext{
${ }^{14}$ Referindo-se àquela legislatura, Martinho Campos considerava a reforma eleitoral de 1881 um marco na dinâmica das relações partidárias porque promoveu uma nova conciliação dentro da Câmara. Anais da Câmara dos Deputados, 24 de janeiro de 1882.
} 
O Sr. Fernandes de Oliveira: - a canoa não pode com tanta gente.

O Sr. Afonso Celso Jr: - eu explicarei tudo oportunamente, desde que os nobres deputados me deem licença para continuar. Nas condições expostas os meus aliados naturais são os liberais...

O Sr. Soares: - são tão monarquistas como os conservadores

O Sr. Afonso Celso Jr: -... mas os liberais de 1831, os liberais da supressão do conselho de estado, da extinção do poder moderador... (ANAIS DA CÂMARA DOS DEPUTADOS, 28/02/1882).

Afonso Celso Jr. apontava a semelhança entre os liberais e os republicanos no projeto de reforma constitucional liberal de 1831, através do qual os moderados se aproximaram dos exaltados para conter as tensões criadas com a abdicação de Pedro I. No plano político nacional, o projeto liberal de 1831 estabelecia a monarquia federativa, o fim do Poder Moderador, Senado eletivo e legislatura de dois anos para a Assembleia Geral, extinção do Conselho de Estado e responsabilidade dos ministros e dos regentes, que também assumiriam as funções não extintas do Poder Moderador. Na esfera políticoeconômica regional, as províncias gozariam de autonomia através das Assembleias províncias, cuja administração separaria os respectivos impostos da arrecadação nacional, entre outras prerrogativas (BRASILIENSE, 1878: 8-10).

Para ele, a instrução pública como item no programa do Partido Liberal aproximava-o da proposta republicana, que tinha a educação como elemento fundamental na conscientização sobre a cidadania no novo regime: "se a república é a forma de governo em que mais direta e eficazmente atua a vontade do cidadão nos negócios públicos, cumpre, antes de tudo, que essa vontade seja esclarecida, para não desvairar [...]". As demais propostas como a autonomia das províncias através do fortalecimento dos municípios, a reorganização da família pelo aspecto civil (legislação sobre o nascimento, o casamento e o óbito), a liberdade religiosa e a proteção da indústria nacional também foram citadas como convergências entre liberais e republicanos (Anais da Câmara dos Deputados, 28 de fevereiro de 1882).

Contraditoriamente, o discurso de Afonso Celso Jr. sobre a escravidão se inclinaria para os conservadores. A abolição era uma questão polêmica, que estava nas ruas e adentrava a Câmara uma década após a Lei do Ventre Livre, provocando a dissensão interna no Partido Liberal e coalizões com o Partido Conservador quando o tema era levantado no plenário. O próprio deputado trouxe o assunto e, embora ele 
houvesse criticado a associação entre escravidão e República como exclusiva dos republicanos paulistas ingressos no Partido Conservador, também seus correligionários liberais engrossavam a fileira antiabolicionista. As ideias de Afonso Celso Jr. sobre o problema em nada diferiam dos colegas parlamentares que cobravam a presença do Estado para conter o avanço do abolicionismo. Contudo, contestavam a ação do Estado sobre a propriedade escrava como interferência na propriedade privada:

[...] se o movimento emancipador não for dirigido por bom caminho, arrastará tudo consigo ao desconhecido. A lei de 28 de setembro de 1871 deu-lhe a solução mais prudente e sensata, mas que os elementos por elas postos em ação não correspondem ao fim desejado prova-o o fato de haver conseguido muito mais que eles a iniciativa individual, pois por cada escravo emancipado pelo Estado a liberalidade particular liberta quatro ou cinco sendo talvez maior a proporção (apoiados) (ANAIS DA CÂMARA DOS DEPUTADOS, 28/02/1882).

O Partido Republicano paulista não assumiu postura francamente combativa à escravidão e também não houve consenso entre os republicanos de outras províncias sobre a questão. A solução para a escravidão não entrava na ordem do movimento republicano, o engajamento era individual, por militantes abolicionistas republicanos e monarquistas. Havia mais convergência entre as três correntes políticas, conservadores, liberais e republicanos, sobre estender a escravidão pelo tempo necessário aos interesses econômicos ou pelo medo da desordem social, sentimento que também unia as diferenças republicanas regionais (ALONSO, 2015: 269; LEMOS, 2009: 417). Os republicanos paulistas dissociaram a escravidão do seu projeto de governo, como Francisco Glicério bem resumiu, em 1884, "nosso objetivo é fundar a República, fato político, não libertar os escravos, fato social”" (ALONSO, 2015: 269).

A maioria dos deputados eleitos em 1881 não se declarou, abertamente, favorável à abolição e a adesão de muitos ao abolicionismo estava condicionada à dependência de apoio político dos padrinhos nos partidos imperiais. Por isso, os parlamentares simpatizantes do abolicionismo assumiam postura cautelosa, defendendo a emancipação gradual ou mesmo deixar que a Lei do Ventre Livre desaparecesse com a escravidão em um futuro distante.

$\mathrm{Na}$ opinião de Afonso Celso, a escravidão era um "problema essencialmente econômico" que não poderia ser resolvido por "meios sentimentais", deveria ser 
solucionado através da Lei do Ventre Livre. Limitando-se ao aumento dos fundos de emancipação e ao incentivo às manumissões privadas, que ele julgava mais válidas do que as praticadas pelo Estado, e sem a imposição de prazos, "medidas indiretas e eficazes sejam adotadas e no sentido emancipador". Como a reforma do trabalho escravo havia se tornado causa pela opinião pública, ele via como necessário agir para tomar o controle sobre esse movimento:

Cumpre, por outra parte, não deixar sem proteção os brancos, antes garantilos em suas pessoas e vidas, e ao mesmo tempo cuidar de tornar os futuros cidadãos dignos de liberdade, cujo mau uso é tão funesto para tudo e para todos (apoiados gerais). Alarguemos a Lei de 28 de setembro, promovamos a abolição por meios sensatos e prudentes, mas não esqueçamos que a libertação dos escravos, como querem alguns, pode trazer a escravização do país à bancarrota e à ruína (apoiados; muito bem e apartes) (ANAIS DA CÂMARA DOS DEPUTADOS, 28/02/1882).

Monarquistas e republicanos concordavam sobre o sentimento de perda de status de senhores, cuja identificação do grupo como "brancos" traduzia a distância vertical entre eles, os proprietários, e o resto da população composta de negros e pardos e brancos pobres, e que seria horizontalizada com fim da escravidão, pois, todos seriam cidadãos. A advertência de Afonso Celso Jr. sobre a necessidade de precaução para preservar o universo dos brancos indica a tensão na incorporação de ex-escravos à cidadania, e as consequências sobre a propriedade como identidade de grupo e modo de vida, indo além da lavoura no sentido apenas econômico.

Afonso Celso Jr. encerrou sua apresentação reafirmando a República que queria, e usou como recurso de retórica uma frase de convocação à luta na Revolução Francesa:

A divisa em meu escudo é a mesma que Leon Gambetta adotou há anos em um banquete de rapazes, e graças à qual de pequeno e obscuro tornou-se em pouco o guia, o orgulho e a consubstanciação de um grande povo: Laborare. [...] Trabalhemos, combatamos, empunhemos com vigor as armas modernas da propaganda da iniciativa, da discussão e do estudo. [...] Às armas, cidadãos! (ANAIS DA CÂMARA DOS DEPUTADOS, 28/02/1882). 
O jovem foi exaltado por colegas e pela plateia, "o orador foi calorosamente cumprimentado e abraçado por muitos srs. Deputados e pelo povo que enchia o recinto", de acordo com as observações do taquígrafo. Após o evento, Martinho Campos pediu a palavra para agradecer o apoio dos correligionários, em especial ao seu "comprovinciano", referindo-se a Afonso Celso Jr.. O político pretendia reduzir a impressão de ousadia do discurso do deputado iniciante, demonstrando que ser republicano não trazia novidade, outros o fizeram antes e terminavam por se adequar aos partidos imperiais e relegar a antiga bandeira,

Esta, porém, é a rota por onde quase todos têm passado. (Riso) É um fato histórico; assim tem sido sempre [...]; alguns políticos, se não tivessem vinda da República quando no regresso, aonde teriam chegado? (Riso) Tem sido uma fortuna, para a causa da liberdade, essas tradições antigas que deixaram sempre no espírito algum vestígio da sua passagem, e de anos a anos, quando saem do governo para a oposição, começam a professar as doutrinas e lições de que eu e outros nos imbuímos (Riso) ((ANAIS DA CÂMARA DOS DEPUTADOS, 28/02/1882).

O presidente do Conselho justificava as ideias republicanas de Afonso Celso Jr., “de uma república evolutiva e platônica", pela imaturidade da juventude. No entanto, os dois políticos, o experiente e o calouro, convergiam sobre a aversão à democracia e ao poder dos presidentes nas recém-criadas repúblicas nas Américas, porque os via como portadores de autoridade sem limites, maior do que a dos reis de monarquias consolidadas:

Não a professo [pela república] pelo mesmo amor a liberdade que tem o nobre deputado. Parece-me que a monarquia mista e representativa me dá mais garantia de liberdade do que a democracia pura; não amo a democracia pura pela mesma razão que não amo a monarquia pura; detesto ambas como instrumentos de despotismo. Nas democracias puras as maiorias têm perfeita garantia para sua liberdade; mas a sorte das democracias é inteiramente precária e sujeita aos arrastamentos das paixões populares e às prepotências das maiorias onipotentes (ANAIS DA CÂMARA DOS DEPUTADOS, 28/02/1882). 
Para ele, as instituições representativas na monarquia preservavam a liberdade porque atuavam pelas mãos de uma minoria que cuidava de cercear os excessos do governante e da sociedade. Assim como Afonso Celso Jr., Martinho Campos não aprovava a ampla participação popular na política, por considerá-la vulnerável aos discursos passionais que atraiam às multidões e fortaleciam o poder arbitrário.

O republicanismo de Afonso Celso Jr. foi ironizado pela Revista Illustrada, que ressaltou a incoerência de sua identificação ora aos liberais, ora aos conservadores. $\mathrm{O}$ excesso de prudência em suas ideias ficou evidente na rejeição do deputado em tratar de questões essenciais, segundo o jornal,

Em tão pouca idade, enfim, jamais se viu tanta moderação. A respeito de todos os problemas importantes, mesmo o do elemento servil, S. Ex. quer tudo, mas conforme as chapas do costume, sem a perturbação da ordem, sem etc., etc... Decididamente é preciso determinar de uma vez, onde acaba a ordem e onde começa a perturbação da ordem (REVISTA ILLUSTRADA, 1882).

A nota ressaltou a ênfase da palavra "ordem" no discurso do jovem deputado, cujo sentido era consenso entre os parlamentares nas diferentes cores partidárias. A preservação da ordem significava manter os mesmos lugares sociais e suas respectivas distinções sob qualquer forma de governo.

As ideias defendidas por Afonso Celso no Parlamento também desagradaram ao Club Republicano Acadêmico, que puniu o deputado com a perda do cargo de "presidente honorário" na agremiação, devido a sua associação ao Partido Liberal e ao governo de Martinho Campos:

O Sr. Dr. Afonso Celso Junior ligando-se a um dos partidos monárquicos representados na Assembleia Geral, com quebra manifesta dos princípios republicanos; dando apoio a um gabinete que não só é naturalmente adverso à política republicana, como cavilosamente contrário às ideias liberais do seu próprios, sustentando com seu voto uma situação cujo chefe governamental é escravocrata declarado. [...] (GAZETA DA TARDE, 19/06/1882).

A Gazeta da Tarde também censurou Afonso Celso Jr. por seu "republicanismo especial", que não representava as ideias republicanas, e do qual todos que discordavam eram “demagogos, Luizas Michel e políticos histéricos”. Segundo o jornal, Afonso Celso 
Jr. representava o "passado", a "tradição miseranda que faz com que o povo considere o atual republicanismo um engodo à corrupção" e a sentença pelo Club Republicano o faria retornar ao campo onde estavam seus eleitores.

\section{Considerações finais}

O republicanismo se definia pelas ideias que remetiam à modernidade em fins do século XIX, democracia elitizada, Estado laico, extinção de privilégios políticos através da elegibilidade de todos os seus cargos, ciência como fundamentação para reformas sociais. Ideário contraposto ao regime monárquico, criticado pela hereditariedade e centralização do poder político, pela associação entre Estado e catolicismo e pela estagnação econômica causada pelo excesso do Estado Imperial.

Em contraste ao regime monarquista associado à inércia, a República era difundida como progresso, entretanto, os ideais republicanos expostos por Afonso Celso Jr. no Parlamento se revestiam de coloração conservadora. As percepções tanto do jovem deputado como do veterano Martinho Campos se assemelhavam sobre a necessidade do governo se efetivar pelo alto, através dos grupos que teriam como prerrogativa definir quem estaria apto a conduzir e a ser conduzido. Afonso Celso Jr. e Martinho Campos estavam atentos à participação popular como ameaça ao mundo que ambos representavam, o primeiro sob o discurso republicano e o político experiente sob o discurso monarquista.

Na concepção conservadora, todo poder é despótico, portanto, o governo popular também o seria, e esta forma de poder significaria a imposição de sua vontade às "elites criativas ou a outros grupos menores de seres humanos" (NISBET, 1987: 85-86). As ideias republicanas defendidas por Afonso Celso Jr. enfatizavam o federalismo e a elegibilidade do Executivo que estruturavam o Estado republicano, através de reformas operadas de dentro para fora, ou seja, pelos agentes já estabelecidos no poder. As mudanças aconteceriam apenas com a substituição da coroa pela posse presidencial, sem provocar desarranjo nas hierarquias sociais e nem abalo nas bases econômicas. Afonso Celso Jr. atribuía à República a liberdade que afirmava não existir na Monarquia, no entanto, não admitia a liberdade fora da ordem imposta pelas elites e igualmente reconhecida e legitimada pela Monarquia. 


\section{Fontes}

ANAIS da Câmara dos Deputados, 24 de janeiro de 1882, p. 217.

ANAIS da Câmara dos Deputados, 28 de fevereiro de 1882, pp.60-66.

ANAIS da Câmara dos Deputados, Fala do Trono, 17 de janeiro de 1882, pp. 115-116.

CORREIO PAULISTANO, n. 6699, 21 de março de 1879, p. 2.

CORREIO PAULISTANO, n. 6721, 20 de abril de 1879, p.1.

GAZETA DA TARDE, n. 13, 23 de julho de 1880, p. 1.

GAZETA DA TARDE, n. 53, 09 de setembro de 1880, p. 1.

GAZETA DA TARDE, n. 67, 25 de setembro de 1880, p. 1.

GAZETA DA TARDE, n. 139, 19 de junho de 1882, p. 1.

GAZETA DA TARDE, n. 127, 04 de junho de 1883, p. 1.

GAZETA DE NOTÍCIAS, n. 350, 18 de dezembro de 1881, p.1.

JORNAL DA TARDE, n. 205, 30 de maio de 1880, p. 2.

JORNAL DA TARDE, n. 226, 21 de junho de 1880, p. 2.

JORNAL DA TARDE, n. 227, 22 de junho de 1880, p. 2.

JORNAL DA TARDE, n. 228, 23 de junho de 1880, p. 2.

JORNAL DA TARDE, n. 237, 04 de julho de 1880, p. 2.

JORNAL DA TARDE, n. 258, 25 de julho de 1880, p. 2.

JORNAL DA TARDE, n. 260, 27 de julho de 1880, p. 2.

REVISTA ILLUSTRADA, ano 7, n. 289, 1882, p. 3.

\section{Referências bibliográficas}

AFONSO, Celso (1998). Afonso Celso de Assis Figueiredo. Oito anos de parlamento. Brasília: Senado Federal.

ALCAÑIZ, Vladimir López (2005). Pensar la república: revolución y positivismo em lós orígines de la terceira república francesa Revista HMiC-2005. Disponível em: <http://www.raco.cat/index.php/HMIC/article/viewFile/22064/21898>. Acesso em: 21 abr 2017.

ALONSO, Alonso (2015). Flores, votos e balas. O movimento abolicionista brasileiro (1868-1888). São Paulo: Companhia das Letras.

BOSI, Alfredo (2007). A máscara e a fenda. In: BOSI, Alfredo. Machado de Assis: o enigma do olhar. São Paulo: WMF Martins Fontes.

BRASILIENSE, Américo (1878). Programas dos partidos e o Segundo Império. São Paulo: Typografia de Jorge Seckler.

CARVALHO, José Murilo de (2007). Liberalismo, radicalismo e republicanismo nos anos sessenta do século XIX. Centre for Brazilian Studies, University of Oxford, Working paper 87.

DEBOM, Paulo (2015). Sob a sombra da águia: mitologia política no Segundo Império Francês. Dimensões, vol. 34.

FRÓES, João Kopke (1960). Afonso Celso, o exilado voluntário de 1889. Revista do IHGB, Rio de Janeiro, 247: 269-281.

GUIMARÃES, Lucia Maria Paschoal (2003). Por uma história ultramontana: Afonso Celso. Intellèctus, v. 2, n. 1. 
HOLANDA, Sergio Buarque de (2008). História Geral da Civilização Brasileira. O Brasil monárquico. Tomo II, v. 7. Do Império à República. $8^{\mathrm{a}}$ Ed. Rio de Janeiro: Bertrand Brasil.

LEMOS, Renato (2009). A alternativa republicana e o fim da monarquia. In GRINBERG, Keila; SALLES, Ricardo (org.). O Brasil Imperial, volume III: 1870-1889. Rio de Janeiro: Civilização Brasileira.

MATTOS, Ilmar Rohloff de (1986). O Tempo Saquarema. Rio de Janeiro: Hucitec.

NISBET, Robert (1987). O Conservadorismo. Lisboa: Editorial Estampa.

Artigo recebido em 26 de abril de 2017.

Aprovado em 17 de agosto de 2017.

DOI: $10.12957 /$ intellectus.2017.31657 